\title{
鉛直方向の腹話術効果に及ぼす音響再生系の影響
}

\section{Evaluation of the Ventriloquism Effect in the Vertical Influenced by Audio Reproduction Systems}

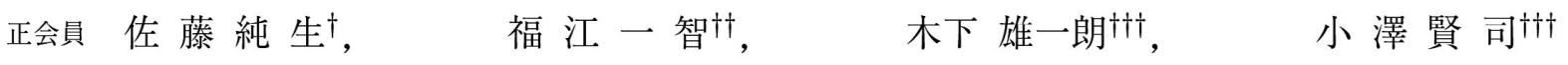

Junsei Sato $^{\dagger}$, Kazutomo Fukue ${ }^{\dagger \dagger}$, Yuichiro Kinoshita ${ }^{\dagger \dagger}$ and Kenji Ozawa ${ }^{\dagger \dagger}$

\begin{abstract}
Vertical orientation on the ventriloquism effect inherent to flat panel display televisions has been evaluated. The stimuli were an image of a metronome and its accompanying sound. These evaluations were aimed at understanding the extent of the effect during real use. The results show that with loudspeakers placed in a low position the effect was too minor to lift a sound image to the upper part on the screen.
\end{abstract}

キーワード : 腹話術効果, 音像定位, スピーカ, 音圧パニング

\section{1. まえ がき}

FPD(Flat Panel Display) 技術の進歩に伴うテレビ画面 の大型化が顕著である. 画面が小さい場合には腹話術効果 ${ }^{1)}$ によって映像と音像との乘離が問題とされることはなかった が, 画面の大型化に伴い, その靟離が懸念されてきている.

これまでにもテレビ視聴時における腹話術効果について 研究がなされてきた 2) 8). 画面が大きい場合には，ステレ 才音像と映像との水平方向の相互作用 2) 4) に加えて, 鉛直 方向の相互作用が話題となる ${ }^{5) \sim 7)}$. 中林 ${ }^{7)}$ によると, 水平 方向において音像が強く引き寄せられるのは, 映像と音像 の開き角が $0^{\circ} \sim 10^{\circ}$ の範囲に留まるのに対して, 鉛直方向 では $17^{\circ}$ の開き角でも音像が映像に引き寄せられている. 更にその影響は水平角度で $20^{\circ}$ 程度まで映像と音像が離れ ている場合にも観測されている。ここで, 先行研究 5) 7)で 使用された実験システムでは，スピーカは視覚的に遮蔽さ れているが，実際のテレビ視聴環境では，スピーカのおお よその位置が視聴者に判別できる場合が少なくない.また,

2008 年 8 月 29 日受付, 2008 年 11 月 4 日再受付, 2008 年 11 月 18 日 採録

†シャープ株式会社 先端映像技術研究所

（产 261-8520 千葉市美浜区中瀬 1-9-2, TEL 043-299-8443) ††山梨大学工学部

( \% 400-8511 甲府市武田 4-3-11, TEL 055-220-8586) ††山梨大学大学院医学工学総合研究部

(广 400-8511 甲府市武田 4-3-11, TEL 055-220-8586)

† Advanced Image Research Laboratories, SHARP Corporation (1-9-2 Nakase Mihama-Ku Chiba 261-8520, Japan)

$\dagger \dagger$ Faculty of Engineering, University of Yamanashi (4-3-11 Takeda, Kofu 400-8511, Japan)

†† Interdisciplinary Graduate School of Medicine and Engineering, University of Yamanashi

(4-3-11 Takeda, Kofu 400-8511, Japan)
同先行研究でのスピーカは画面の両脇に設置され，その高 さは画面の中心位置よりやや下となっているが, 現在市場に 出ている薄型テレビは，画面下端よりもさらに下にスピー カが設置されているモデルが多い. 以上のように，先行研 究の実験条件と実際のテレビ視聴環境には少なからず差異 がある。そこで本稿では，実際の視聴環境での音響再生系 が, 鉛直方向の腹話術効果にどのような影響を及ぼすのか について検討を行った。

\section{2. 実 験 方 法}

\section{1 実験環境}

本研究では, 実機による検証を行うため, 液晶テレビおよ びラックスピーカシステムとして (a) 液晶テレビ : SHARP AQUOS LC-65RX1W (アンダースピーカ : $10 \times 4 \mathrm{~cm} \times$ 2 個, $\phi 2.0 \mathrm{~cm} \times 2$ 個, $\phi 5.5 \mathrm{~cm} \times 1$ 個)，(b) ラックシス テム :SHARP AQUOS オーディオ AN-ACR1 (スピーカ: $\phi 10.0 \mathrm{~cm} \times 2$ 個, $\phi 2.5 \mathrm{~cm} \times 2$ 個, $\phi 16.0 \mathrm{~cm} \times 1$ 個 $)$ を 用いた. また, 先行研究 5) -7) との比較も考慮し, テレビ側 方の外付けスピーカとして (c) 外付けスピーカ:YAMAHA NS-3MX (方式:1ウェイ・バスレフ・ブックシェルフ型, 単 一音源とするためにバスレフの穴を粘土で塞いで使用, 使 用ユニット：全帯域用， $\phi 12 \mathrm{~cm} コ$ コ型）を用いた。な お，音響系の機能設定については，工場出荷時の值とした。 これらの機材を図 1 に示すとおりに配置した。提示する

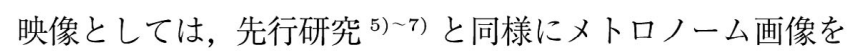
用い, 画面中央で仰角 $17^{\circ}, 7^{\circ}$ および $-3^{\circ}$ の 3 種類の位 置の一つに提示した。ただし，本実験では図 2 に示すよう に, 実際のメトロノームを撮影して映像として用いたため, 先行研究 5) 7) で用いられた画像 (W: 最大部で片側 $4^{\circ} \times$ 


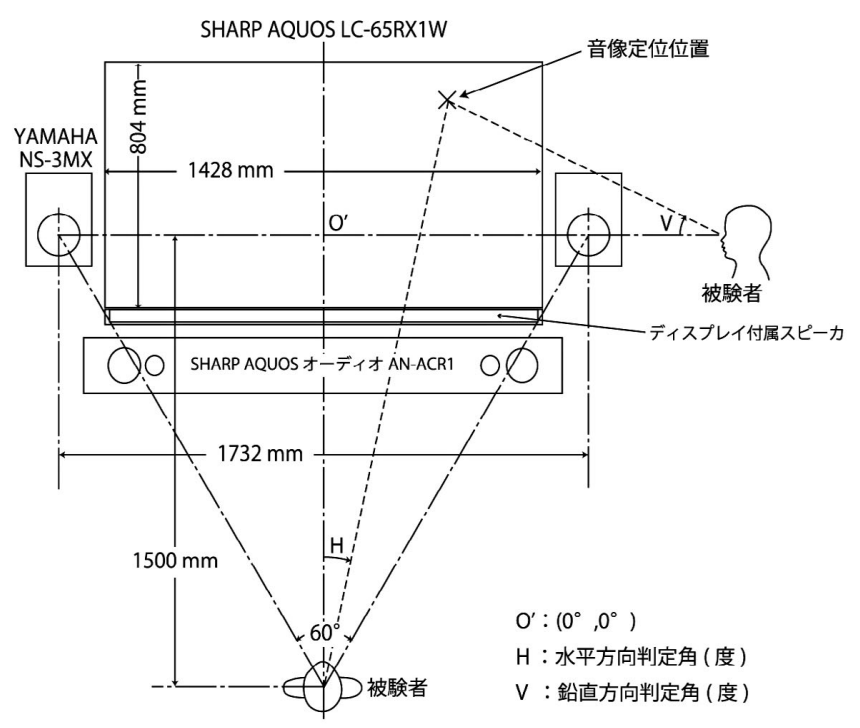

図 1 実験配置図

Arrangement for the experiments.

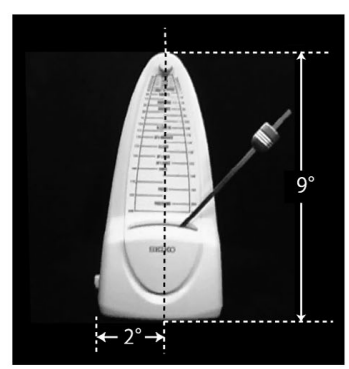

図 2 メトロノーム映像（針の支点位置を映像の位置とする） Picture of a metronome. The position of the pendulum pivot represents its visual image location.

$\left.\mathrm{H}: 9^{\circ}\right)$ に比べると, 高さの見込み角はほぼ等しいが横幅は 小さい. 音刺激は, 先行研究 ${ }^{6) 7)}$ を参考にして, 左右チャネ ルのレベル差を以下の 11 通り $(-20,-12,-8,-4,-2,0$, $2,4,8,12,20 \mathrm{~dB})$ のいずれかに設定して再生した. 聴取 位置での音圧レベルは $70 \mathrm{~dB}$ とした. また，それぞれのス ピーカ系に接続された 3 台の MIDI 音源 (Roland, SD-20) のいずれかを用いて，メトロノームの音色を 60 拍/分で 5 回分提示した. なお, 先行研究 ${ }^{5) \sim 7) ~ て ゙ は, ~ カ ー テ ン に よ っ ~}$ てスピーカを視覚的に遮蔽していた。しかし，実際の視聴 環境においては，スピーカの位置は視聴者にとって既知で あることが多い. 本研究では, 実際の環境で視聴者が知覚 する現象を観測するために, 視覚的な遮蔽は行わないこと とした。ここで， 3 種類のスピーカ系の音質の影響につい ては, 複数の評定者からの内観報告により, 音質でスピー カ系を判定することは困難であったことが確認されている.

\section{2 実験手順}

実験条件の組合せは 3 (スピーカ系) $\times 4$ (映像なし十仰 角 3 条件） $\times 11$ (左右レベル差) $=132$ 通りであり，同一 条件の判定回数は 5 回である.すなわち, 被験者一人あた りの総試行回数は 660 回であり，これを 3 セッションに分 けて実施した．各セッションの冒頭には，黒色画面の左右 中央で仰角 $0^{\circ}$ の位置にメ印 $\left(\right.$ 視覚約 $1^{\circ}$ ) を約 2 秒間提示し,
被験者に注視するように教示した，その後，上記の実験条 件をランダム順に実施した。このとき被験者には映像を注 視するよう教示した．刺激提示時間は上述のとおり，メト ロノーム 60 拍/分の 5 拍分であるから 5 秒間である. 被験 者は着座して映像抢よび音刺激の提示を受け，その終了後 5 秒以内にマウスで画面上をクリックすることにより，音 像が定位した位置を回答した。なお，被験者には，どのス ピーカを使用するかは教示せずに実験を行った。被験者は 20 歳代の 11 名である.

\section{3. 実験結果および考察}

\section{1 スピーカ系ごとの音像定位位置}

全実験結果に関する分散分析を実施したところ，要因「ス ピーカ系」が関係する交互作用が有意であったので，本節 では 3 種のスピーカ系ごとに検討する．横軸を左右レベル 差とし, 縦軸を音像定位位置の仰角として表示した実験結 果を図 3 に示す．グラフの縦軸の範囲は，画面の上下の端 に対応する。なお，誤差棒は全データについての標準偏差 を示しているが，重なって見づらくなることを防ぐために 上側または下側のみに表示し, かつ映像条件ごとにデータ を左右にずらして表示した。

四から, 映像の有無・提示角度によって音像の定位位置 が鉛直方向で変化する腹話術効果があることがわかる。た だし，表 1 に被験者内計画モデルによる分散分析表の一例 として (a) ディスプレイ付属スピーカ系の場合を示すとお り, 各スピーカ系について交互作用「映像 $\times$ 左右レベル差」 が有意であり，映像が音像定位位置に及ぼす影響は左右の 音圧レベル差が大きくなると収斂する傾向が見られる（他 のスピーカ系についての交互作用の有意性：(b) ラックシ ステムでは $F(15,150)=2.318, p<.01$, (c) 外付けでは $F(15,150)=1.913, p<.05)$. 要因「映像」の単純主効 果を検討するために，代表的な条件として，画面中央付近 $(0 \mathrm{~dB}$ 条件の結果) と両端付近 $(20 \mathrm{~dB}$ および $-20 \mathrm{~dB}$ 条 件の結果）を取り上げて分析を行う。まず，画面中央付近 について下位検定を行い, どの映像条件間で有意差が生じ るかを調べた。その結果を, 音像の仰角 (平均值) が降順 となるように映像条件を左から列挙し, LSD 検定による多 重比較の結果として有意差のない組合せを下線で結ぶこと で以下に表示する。

(a) デイスプレイ付属： $17^{\circ} 7^{\circ}$ 映像なし $-3^{\circ}$

(b) ラックシステム： $17^{\circ} \quad 7^{\circ}$ 映像なし $\quad-3^{\circ}$

(c) 外付け： $\quad 17^{\circ} \quad 7^{\circ}$ 映像なし $-3^{\circ}$ 次に, 画面両端付近においても要因「映像」が有意であっ たので, 同様な多重比較を行った結果を以卜に示す.
(a) ディスプレイ付属： $17^{\circ} 7^{\circ}$ 映像なし $-3^{\circ}$
(b) ラックシステム： $17^{\circ} \quad 7^{\circ}$ 映像なし $-3^{\circ}$
(c) 外付け： $\quad 17^{\circ} \quad 7^{\circ}$ 映像なし $\quad-3^{\circ}$

以上のように，画面の中央に映像を提示した場合について の鉛直方向の腹話術効果は, 画面の両端付近では小さくな 


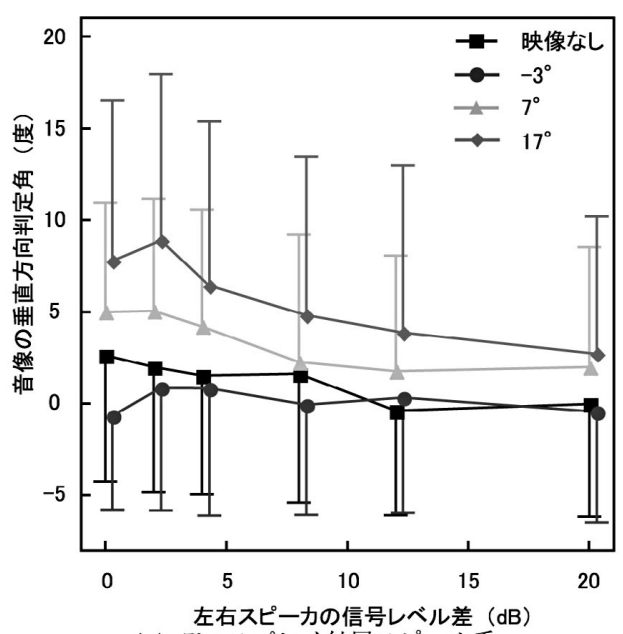

(a) ディスプレイ付属スピーカ系

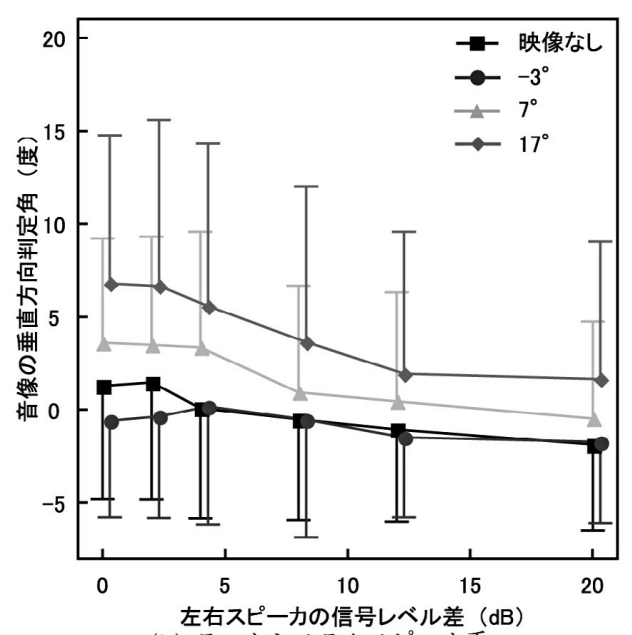

(b) ラックシステムスピーカ系

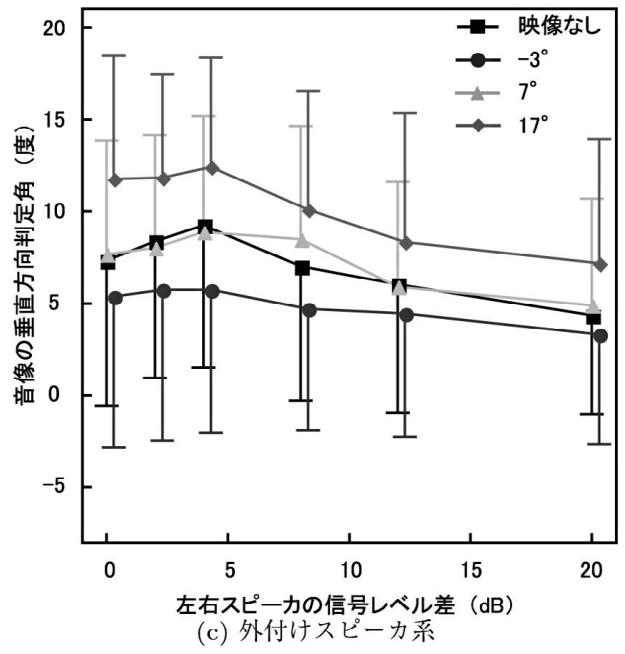

図 3 音像の仰角

Elevations in sound localization.

\section{ることが示された.}

\section{2 スピーカ系の相違による音像定位位置の相違}

本節では，スピーカ系の相違による実験結果の相違に着 目して検討する。ここでも，左右レベル差が $0 \mathrm{~dB}$ の場合 と $20 \mathrm{~dB}$ および $-20 \mathrm{~dB}$ の場合を取り上げ，提示した映像 の仰角を横軸に，音像定位位置の仰角を縦軸にとったグラ フを図 4 に示す.この図から，鉛直方向の腹話術効果の量
表 1 音像の仰角に関する分散分析表-(a) デイスプレイ付属ス ピーカ系

Results of ANOVA for elevations in sound localization.

\begin{tabular}{lrrrr}
\hline \hline \multicolumn{1}{c}{ 要因 } & \multicolumn{1}{c}{ SS } & \multicolumn{1}{c}{ df } & \multicolumn{1}{c}{ MS } & \multicolumn{1}{c}{$F$} \\
\hline 被験者の個人差 $(\mathrm{S})$ & 56387.3 & 10 & 5638.7 & \\
\hline 咉像（Image） & 10412.0 & 3 & 3470.7 & $12.078^{* *}$ \\
$\mathrm{~S} \times$ Image & 8620.4 & 30 & 287.3 & \\
\hline 左右レベル差 (Level) & 3322.0 & 5 & 664.4 & $10.994^{* *}$ \\
$\mathrm{~S} \times$ Level & 3021.6 & 50 & 60.4 & \\
\hline Image $\times$ Level & 1495.4 & 15 & 99.7 & $3.439^{*} *$ \\
$\mathrm{~S} \times$ Image $\times$ Level & 4349.0 & 150 & 29.0 & \\
\hline 全体 & 87607.8 & 263 & & \\
\hline
\end{tabular}

SS: Sum of Square, df: degree of freedom, MS: Mean Square $* * p<.01$

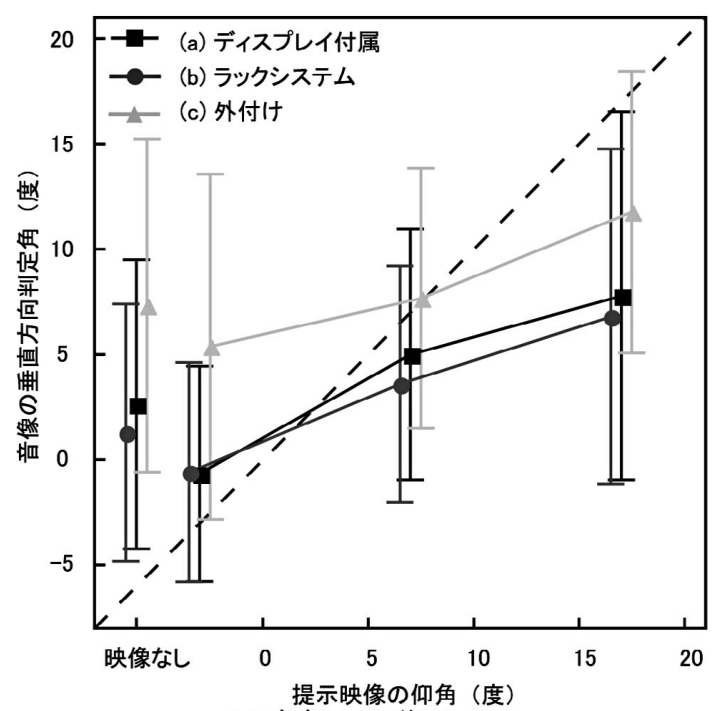

(a) 左右レベル差: $0 \mathrm{~dB}$

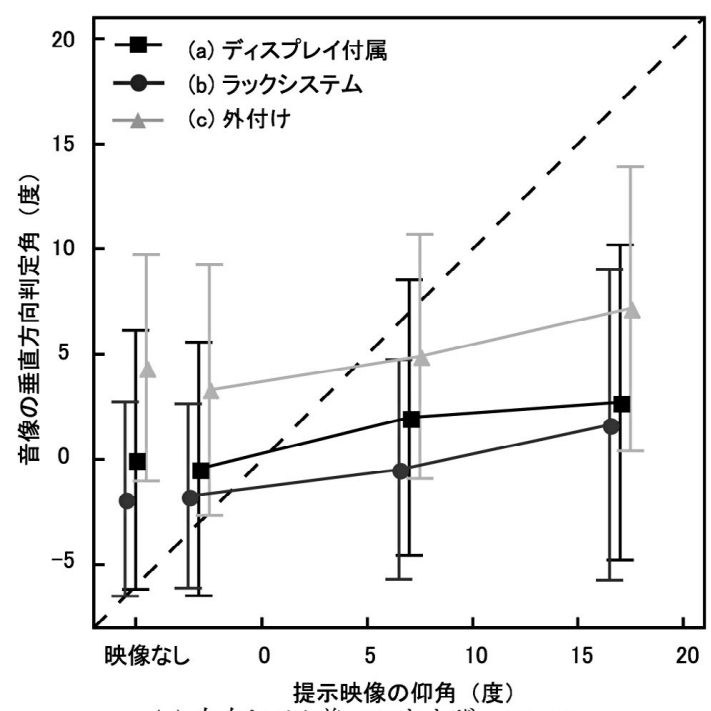

(a) 左右レベル差: 20 および $-20 \mathrm{~dB}$

図 4 提示映像の仰角と音像の仰角の関係 Relation between the elevations of the presented images and sound localization.

としては，木実験で取り上げた 3 種のスピーカ系について 同様であることがわかる。ただし， $0 \mathrm{~dB}$ 条件の場合に比べ て, $20 \mathrm{~dB}$ および $-20 \mathrm{~dB}$ 条件の場合に, 腹話術効果が小 さいのは前節で述べたと扝りである。また，スピーカが画 面より下側にある (a) ディスプレイ付属や (b) ラックシス 
テムのスピーカ系では, (c) 外付けスピーカ系に比べて音像 が下部にあり，特に提示映像の仰角が $17^{\circ}$ の場合には，映 像位置との乘離は大きくなっている，音像の仰角について 要因「スピーカ系」の単純主効果に関する多重比較の結果 を，まず左右レベル差が $0 \mathrm{~dB}$ の場合について以下に示す.
・映像なし：
(c) 外付け
(a) 付属
(b) ラック
- 仰角 $-3^{\circ}$ :
(c) 外付け
(a) 付属
(b) ラック
- 仰角 $7^{\circ}$ :
(c) 外付け
(a) 付属
(b) ラック
- 仰角 $17^{\circ}$ :
(c) 外付け
(a) 付属
(b) ラック

続いて, 左右レベル差が 20 および-20 dB の場合につい て以下に示す.
・映像なし：
(c) 外付け
(a) 付属
(b) ラック
- 仰角 $-3^{\circ}$ :
(c) 外付け
(a) 付属
(b) ラック
·仰角 $7^{\circ}$ :
(c) 外付け
(a) 付属
(b) ラック
- 仰角 $17^{\circ}$ :
(c) 外付け
(a) 付属
(b) ラック

以上のとおり，(c) 外付けスピーカ系による音像仰角が有意 に上にある. (a) ディスプレイ付属と (b) ラックシステム のスピーカ系は, 画面中央では有意差がない場合が多いが, 画面両端では有意差が生じている。これは，両端付近では スピーカの実体に近く, その物理的な上下の関係が反映さ れているものと考える.

\section{3 考 察}

3.1 節では，画面中头に映像を提示した場合，左右両端 付近では鉛直方向の腹話術効果が小さくなることが示され た. また, 3.2 節では, (a) ディスプレイ付属系と (b) ラッ クシステム系が (c) 外付けスピーカ系よりも音像仰角が下 となり, 図 4 に示すように (c) 外付けスピーカ系の場合で さえ, 音像の追随性が良いとはいい難い結果となった。こ れらは先行研究 5) 7) の結果とは異なるものであり, その原 因として，スピーカを視覚的に遮蔽しないなど視聴環境を 想定した本実験条件の, 先行研究に対する差異が挙げられ る. 以上の結果から，画面より下側に設置されたスピーカ 系を用いた場合には, 腹話術効果たけで画面上方に音像を 定位させることは困難であることが示された，今後に，映 像と音像との乘離を小さくすることを目指した音響再生シ ステムを考案する必要性が示唆されたものと考えている.

\section{4. むす び}

本研究では，大型液晶テレビの実機を用いて鉛直方向の 腹話術効果について検討を行った. その結果, ディスプレ イ付属のアンダースピーカ系やラックシステムのスピーカ 系により (工場出荷時の設定で) 音を提示した場合には，腹 話術効果だけで画面上オに音像を定位させることは困難で あることが示された。

\section{〔文献〕}

1) G. M. Stratton: "Vision without inversion of the retinal image", Psychol. Rev., 4, pp. 341-360 (1897)

2）中林克己, 辻本廉, 二階堂誠也: “ステレオ音像とテレビ映像の相互作用 に関する基礎実験”, 昭 54 春季日本音響学会講演論文集, pp. 245-246 (Mar. 1979)
3）中林克己, 辻本廉, 二階堂誠也: “ステレオ音像とテレビ映像の相互作用に 関する基礎実験 (2)”, 昭 54 秋季日本音響学会講演論文集, pp. 293-294 (Oct. 1979)

4）中林克己, 过本廉, 二階堂誠也: “ステレオ音像とテレビ映像の相互作用 に関する基礎実験 (3) 一注目度の定量化について一”, 昭 55 春季日本 音響学会講演論文集, pp. 113-114 (Mar. 1980)

5）小宮山搔, 中林克己, 辻本廉, 二階堂誠也: “大画面テレビ映像とステレオ 音像の相互作用に関する基礎実験 —垂直方向の音像定位について—”, 昭 56 春季日本音響学会講演論文集, pp. 613-614 (Mar. 1981)

6）小宮山摂, 中林克己, 二階堂誠也: “大曲面テレビ映像とステレオ音像の 相互作用に関する基礎実験—垂直方向の音像定位について (2)—”，昭 56 秋季日本音響学会講演論文集, pp. 225-226 (Oct. 1981)

7）中林克己：“ステレオ音像とテレビ映像の相乗効果”, テレビ誌, 37, 12 , pp. 984-991 (Dec. 1983)

8）小宮山摂：“大画面テレビ視聴時における音像定位”，音響誌， $\mathbf{4 3}, 9$, pp. 225-226 (Sep. 1987)

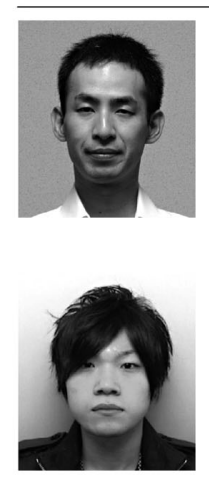

佐藤竞純出生 1999 年, 東北大学大学院工学研究科 修士課程修了. 同年, シャープ株式会社に入社. 正会員.

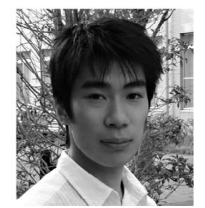

福江 かずと智 2004 年, 山梨大学工学部コンピュー 夕・メディア工学科情報メディアコース入学. 音響工学 に関する研究に従事.

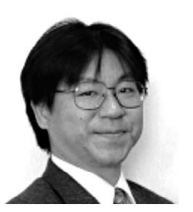

きのした栗ういちろう 雄一朗 2007 年, 立命館大学大学院理工学研 究科一貫制博士課程フロンティア理工学専攻修了. 同年 より, 山梨大学大学院医学工学総合研究部助教. 博士 (工 学). ヒューマンインタフェース, ヒューマンファクター, 感性工学に関する研究に従事.

小澤 掔司 1988 年, 東北大学大学院修士課程修 了. 同年, 東北大学電気通信研究所助手. 東北大学助教 授，山梨大学助教授を経て，2007 年，山梨大学大学院医 学工学総合研究部教授. メディア感性工学, 音響信号処 理などの研究に従事. 